\title{
MOF-Derived CuPt/NC Electrocatalyst for Oxygen Reduction Reaction
}

\author{
Rehan Anwar 1,2, Naseem Iqbal 1,*(D), Saadia Hanif 1,2, Tayyaba Noor ${ }^{3}$, Xuan Shi ${ }^{2}$, \\ Neelam Zaman ${ }^{1}$, Daarain Haider ${ }^{1}$, Syed Aun M. Rizvi ${ }^{1}$ (D) and A. M. Kannan ${ }^{2, *(D)}$ \\ 1 Energy Storage and Conservation Lab, USPCAS-E, National University of Sciences and Technology, \\ Islamabad 44000, Pakistan; rehanrevo@gmail.com (R.A.); saadiah_hanif@yahoo.com (S.H.); \\ neelamzaman6650@gmail.com (N.Z.); haider.daarain@gmail.com (D.H.); \\ syedaunn51214@gmail.com (S.A.M.R.) \\ 2 Fuel Cell Laboratory, The Polytechnic School, Ira A. Fulton Schools of Engineering, Arizona State University, \\ Mesa, AZ 85212, USA; sxuan2@asu.edu \\ 3 SCME, National University of Sciences and Technology, Islamabad 44000, Pakistan; \\ tayyaba.noor@scme.nust.edu.pk \\ * Correspondence: naseem@uspcase.nust.edu.pk (N.I.); amk@asu.edu (A.M.K.)
}

Received: 31 May 2020; Accepted: 14 July 2020; Published: 17 July 2020

check for updates

\begin{abstract}
Metal-organic frameworks (MOFs) have been at the center stage of material science in the recent past because of their structural properties and wide applications in catalysis. MOFs have also been used as hard templates for the preparation of catalysts. In this study, highly active $\mathrm{CuPt} / \mathrm{NC}$ electrocatalyst was synthesized by pyrolyzing Cu-tpa MOF along with Pt precursor under flowing $\mathrm{Ar}-\mathrm{H}_{2}$ atmosphere. The catalyst was characterized by scanning electron microscopy (SEM), transmission electron microscopy (TEM), X-ray photoelectron spectroscopy (XPS), and X-ray powder diffraction (XRD). Rotating disk electrode study was performed to determine the oxygen reduction reaction (ORR) activity for $\mathrm{CuPt} / \mathrm{NC}$ in $0.1 \mathrm{M} \mathrm{HClO}_{4}$ at different revolutions per minute $(400,800,1200$, and 1600) and it was also compared with commercial $\mathrm{Pt} / \mathrm{C}$ catalyst. Further the ORR performance was evaluated by K-L plots and Tafel slope. CuPt/NC shows excellent ORR performance with onset potential of $0.9 \mathrm{~V}$ (vs. RHE), which is comparable with commercial Pt/C. The ORR activity of CuPt/NC is demonstrated as an efficient electrocatalyst for fuel cell.
\end{abstract}

Keywords: Cu-tpa MOF; PEMFC ORR electrocatalyst; CuPt/NC; platinum

\section{Introduction}

Fossil fuels are neither a clean nor sustainable source of energy. Therefore, the global energy is going through a transition from fossil fuels to clean and sustainable energy resources [1]. To resolve the rising global energy crisis and the related environmental problems, an immense deal of research attention has been paid for developing substitute green energy conversion and storage technologies, together with water splitting, metal-air batteries, and fuel cells in the past decade [2]. Oxygen reduction reaction electrocatalysis is one of the mainly considered topics because of its significance for electrochemical energy conversion and storage devices. In electrochemical systems it deals with the oxygen electrode reactions. A prevalent interest intended for the electrochemical oxygen reduction reaction has two facets. The following reaction attracts substantial consideration from basic research point of view; in addition to this, it is the most significant reaction for energy conversion application in electrochemical energy devices. It has been focused in theoretical study as $4 \mathrm{e}^{-}$reaction, incredibly sensitive to the surface structural and electronic characteristics. It might consist of a number of elementary reactions [3]. Moreover, oxygen reduction reaction (ORR) is the reaction happening at the cathode, which presides over the energy transfer efficiency of fuel cells. 
In aqueous solution, the ORR is exceedingly irreversible and consists of many adsorptions/ desorption reaction steps involving oxygen-containing species i.e., $\mathrm{O}, \mathrm{O}_{2}{ }^{-}, \mathrm{OH}, \mathrm{HO}_{2}^{-}$, and $\mathrm{H}_{2} \mathrm{O}_{2}$. Regardless of extensive research work for more than a decade, the mechanistic portion of oxygen reduction have not been well understood because of the involvement of net transfer of $4 \mathrm{e}^{-}$and 4 protons to oxygen and $\mathrm{O}_{2}$ formal double bond cleavage. Beside its scientific significance, oxygen electrocatalysis is significantly important to the industry, mainly because of the rising demands for renewable energy technologies that depends on oxygen reduction electrochemistry, for example fuel cells, fuel synthesis, metal-air batteries, electrocatalytic, and photocatalytic water splitting etc., [4,5].

The ORR in acidic media at $25^{\circ} \mathrm{C}$ versus RHE at standard conditions, the thermodynamic potential is presented as follow [6]:

$$
\mathrm{O}_{2}+4 \mathrm{H}^{+}+4 \mathrm{e}^{-} \rightarrow 2 \mathrm{H}_{2} \mathrm{O} \quad \mathrm{E}=1.230 \mathrm{~V}
$$

Fuel cell converts chemical energy of fuel $\left(\mathrm{H}_{2}\right.$, Methanol, etc.,) directly into electrical energy. Proton exchange membrane fuel cell (PEMFC) is one such efficient and clean energy conversion device with high efficiency and environmental compatibility. PEMFC can be used in both stationary as well as portable applications because of their high power density and low temperature operation as compared to other fuel cells [7-9]. Moreover, it fascinates worldwide attention as they can proficiently convert chemical energy of $\mathrm{H}_{2}$ into electricity. Though, the PEMFC systems prevalent commercialization remains limited, it needed high Pt metal content to compensate the sluggish ORR kinetics happening at cathode in device.

Presently, platinum supported on carbons $(\mathrm{Pt} / \mathrm{C})$ has been considered as the best catalyst for ORR and has been extensively considered as the state-of-the-art catalysts for ORR because of their high activity, even though it still undergoes multiple drawbacks, including fuel crossover, together with its susceptibility to time-dependent drift and CO poisoning. So far the limited commercialization of PEMFC is associated with the high cost of the durable Pt catalyst [10-12]. Currently a lot of efforts are being made to minimize the use of Pt catalyst in PEMFC. ORR is crucial in PEMFC as it directly affects the current density which pays a vital role in overall fuel cell performance. However, the exploitation of noble metals is greatly pertinent in the research progress of PEMFCs, as electrocatalysts based on expensive Pt metal are still extensively used. This is predominantly important in the case of the ORR. In order to lessen the expenses of cathode electrocatalysts, the quantity of noble metal is aimed to decrease, yet sustaining a high catalytic activity for the ORR [13]. Recently, researchers demonstrated by constructing different Pt-based materials possessing, certain geometrical composition and configuration can be achieved in order to get better activity with higher utilization of precious metal active sites. The ORR kinetics can be improved by alloying noble metals (Pt, $\mathrm{Pd}$ ) with $\mathrm{Cu}, \mathrm{Ni}, \mathrm{Co}$, and $\mathrm{Fe}$.' Regardless of remarkable efforts, developing oxygen reduction electrode catalysts with elevated activity at low costs remains a striking challenge [12,14-17]. However, the performance of such transition metals blended $\mathrm{Pt}$ materials for ORR still needs considerable improvements. Additionally, stability persists to remain a major apprehension in acidic electrolyte. This deficiency in catalytic activity has been ascribed to hydrogen peroxide $\left(\mathrm{H}_{2} \mathrm{O}_{2}\right)$ formation through an indirect oxygen reduction, dissolution of the metal and corrosion of the carbon support [18].

Metal-organic frameworks (MOFs) have been proved as emerging and advanced materials for multiple applications especially in catalysis because of their highly porous structures [19-22]. MOFs have also been used as precursors for synthesis of nanocomposites. They have micro-pores and low graphitic degree which is not desirable for electrochemical activity [10-13]. The pyrolysis of MOFs can be used to create highly porous structures which are stable at higher temperature and have much higher electrochemical activity [14-16]. In addition, MOF-derived carbon based electrocatalyst provide better mass transport in electrochemical reaction because of its porous morphology. Moreover, the uniform distribution of metal over MOF precursors offer the effective utilization of catalyst active sites [23]. Rui Wang and co-workers designed a porous carbon matrix with phosphorous and 
nitrogen doping using $\mathrm{Cu}-\mathrm{MOF}$, this catalyst exhibited a remarkable performance as a bi-functional electrocatalyst for ORR and hydrogen evolution reaction (HER) [24].

In this study, a novel electrocatalyst for ORR was successfully synthesized by pyrolysis of $\mathrm{Cu}$-tpa MOF with very low Pt loading. This Cu-tpa MOF-derived electrocatalyst has nano-porous carbon (NC) formed in its structure. The ORR performance of the $\mathrm{CuPt} / \mathrm{NC}$ is comparable with commercial $\mathrm{Pt} / \mathrm{C}$.

\section{Results and Discussion}

A detailed literature review was conducted to devise a synthesis technique for Cu-tpa MOF [25-27]. Figure 1 shows the FTIR spectra of $\mathrm{Cu} / \mathrm{NC}, \mathrm{Cu} \mathrm{Pt} / \mathrm{NC}$, and $\mathrm{Cu}$-tpa MOF. The peaks for $\mathrm{C}-\mathrm{H}$ stretching vibrations are at $1106 \mathrm{~cm}^{-1}$ and $1174 \mathrm{~cm}^{-1}$. Whereas, peaks positioned at $1384 \mathrm{~cm}^{-1}$ and $1610 \mathrm{~cm}^{-1}$ are characterized for $\mathrm{C}-\mathrm{H}$ and $>\mathrm{C}=\mathrm{C}<$ stretching bonds. Furthermore, peaks at $2373 \mathrm{~cm}^{-1}, 3440 \mathrm{~cm}^{-1}$ correspond to the presence of carbonates and $\mathrm{O}-\mathrm{H}$ bonds absorbed on the surface $[4,28,29]$.

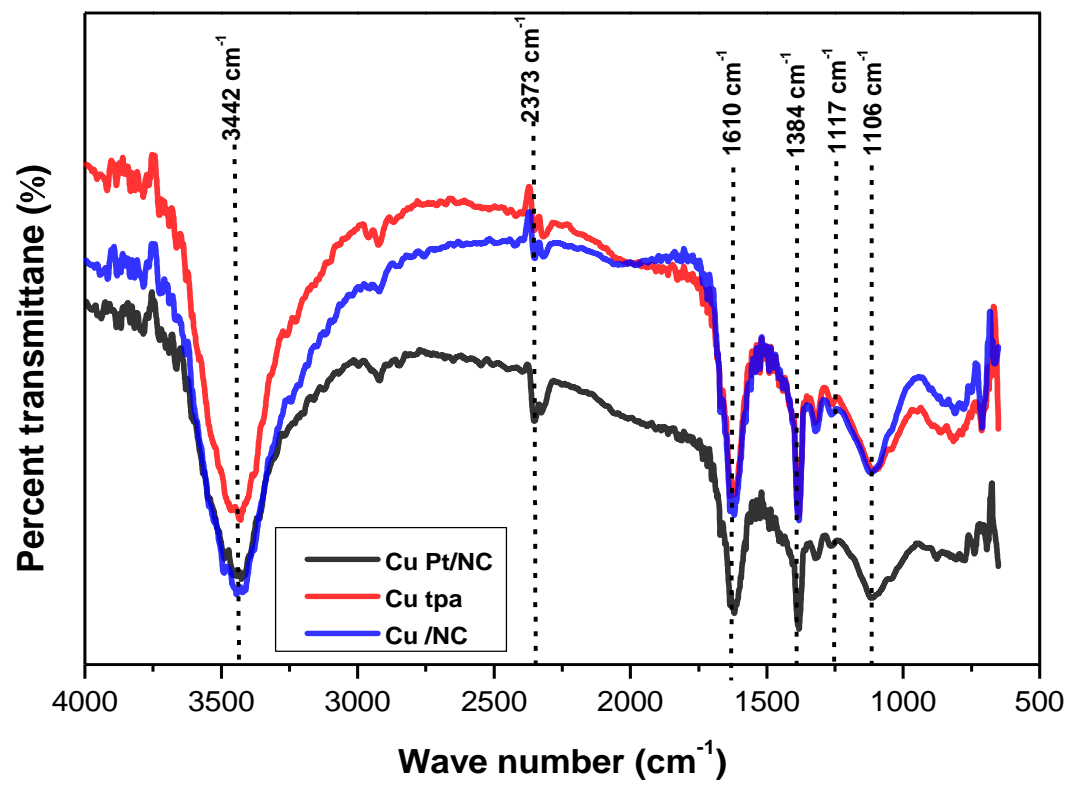

Figure 1. FTIR of $\mathrm{Cu} / \mathrm{NC}, \mathrm{CuPt} / \mathrm{NC}$, and $\mathrm{Cu}$-tpa metal-organic frameworks (MOF).

Figure 2 shows SEM images with same magnification for $\mathrm{Cu}$-tpa $\mathrm{MOF}, \mathrm{Cu} / \mathrm{NC}$, and $\mathrm{CuPt} / \mathrm{NC}$. The average $\mathrm{Cu}$-tpa MOF particle size is around $2 \mu \mathrm{m}$, these particles do not possess specific and regular shape but shows a good crystallinity [27]. After pyrolysis, the sample was transformed into a black powder because of the carbonization of organic linker (Figure $2 b, c)$.
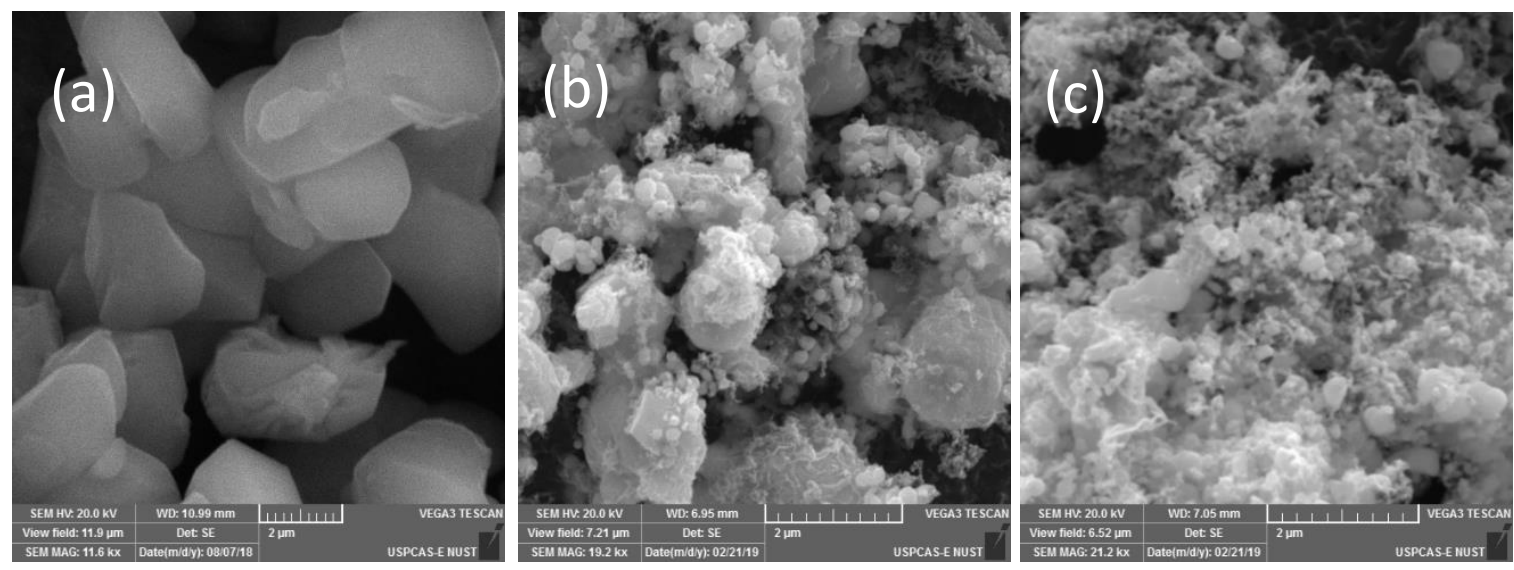

Figure 2. Scanning electron microscopy images of (a) Cu-tpa MOF, (b) $\mathrm{Cu} / \mathrm{NC},(\mathbf{c}) \mathrm{CuPt} / \mathrm{NC}$. 
During the process of pyrolysis, the Cu-tpa MOF decomposes partially as the unstable organic groups evaporate, leaving only the nano-porous carbon behind. Figure $2 b, c$ illustrate the formation of nano-porous carbon onto the surface of $\mathrm{Cu}$-tpa particles. With Pt loading surface becoming more rough and porous, that can be observed in Figure 2c.

Figure 3 shows the EDS spectrum of all three samples including $\mathrm{Cu}$-tpa MOF, $\mathrm{Cu} / \mathrm{NC}$, and $\mathrm{CuPt} / \mathrm{NC}$. Carbon, oxygen, and copper peaks are visible in all three samples, while the Pt peak is observed only in $\mathrm{CuPt} / \mathrm{NC}$. Likewise, the elemental percentages from EDS are shown in the Table 1. Cu-MOF has the highest percentage of carbon while the other two pyrolyzed samples have relatively lower percentage of carbon as the unstable organic groups have evaporated after the pyrolysis which also decreases the carbon percentage. The relative percentage of $\mathrm{Cu}$ is increased after pyrolysis as seen in Table 1. Because of the very low Pt loading, the EDS only shows $1 \mathrm{wt} \%$ of Pt loading in $\mathrm{CuPt} / \mathrm{NC}$ because of the limited selection of area for EDS, while the actual loading of Pt was $10 \%$.
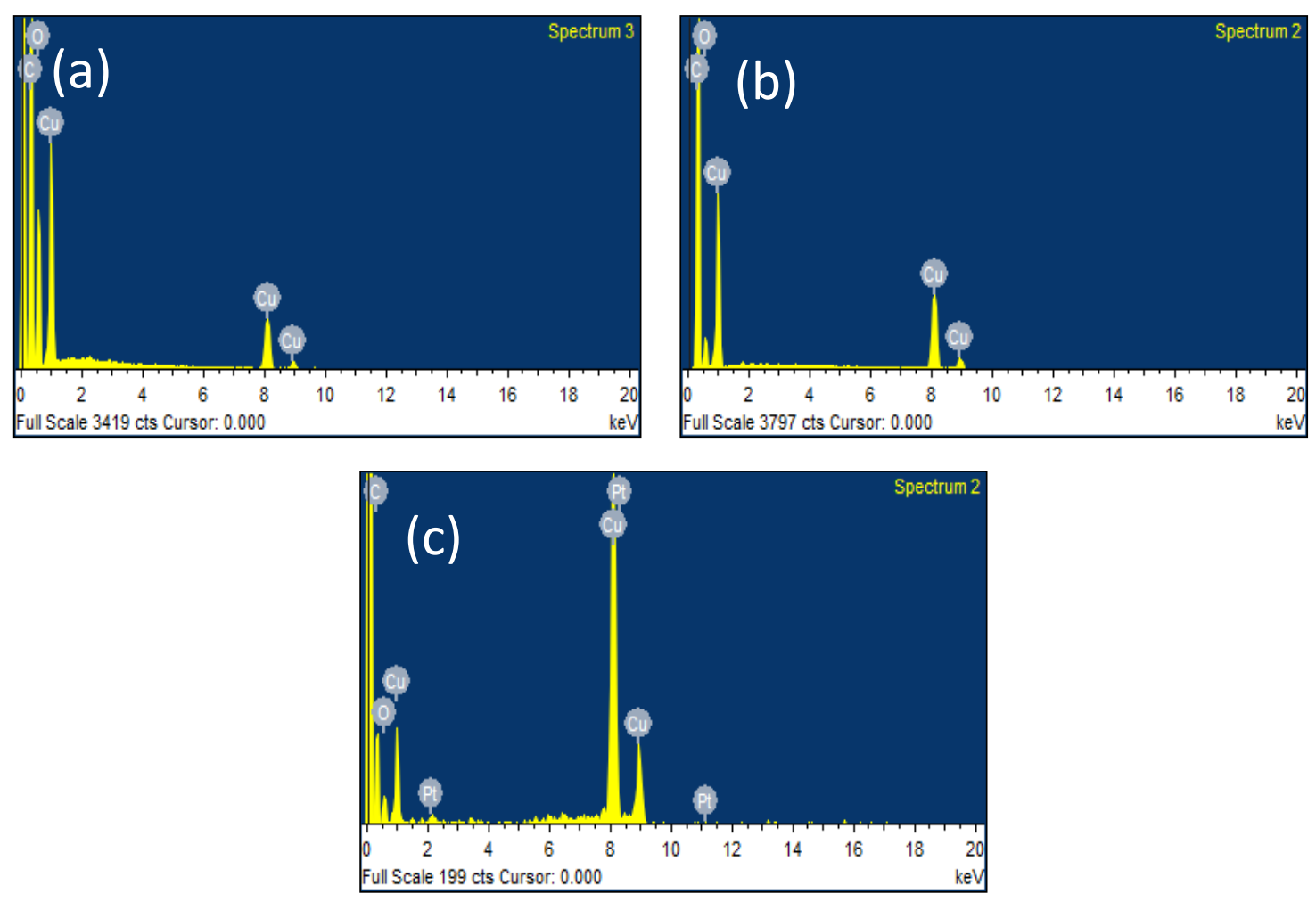

Figure 3. Energy dispersive $\mathrm{X}$-ray spectroscopy of (a) Cu-tpa $\mathrm{MOF},(\mathbf{b}) \mathrm{Cu} / \mathrm{NC}$, (c) $\mathrm{CuPt} / \mathrm{NC}$.

Table 1. Weight percentage in EDS analysis.

\begin{tabular}{cccc}
\hline Elements & Cu-tpa MOF & Cu/NC & CuPt/NC \\
\hline C wt $\%$ & 71.46 & 66.88 & 51.01 \\
O wt \% & 9.52 & 9.60 & 8.01 \\
Cuwt \% & 19.01 & 23.51 & 39.95 \\
Pt wt \% & - & - & 1.03 \\
\hline
\end{tabular}

To study the morphologies and size of $\mathrm{Cu} \mathrm{Pt} / \mathrm{NC}$, TEM images were recorded as shown in Figure 4. From the TEM images it can be observed that the pyrolyzed sample contains numerous small $\mathrm{CuPt}$ nanoparticles distributed uniformly on carbon matrix (Figure 4a). The size of CuPt/NC is nearly $5-7 \mathrm{~nm}$ (Figure $4 b$ ) as depicted from TEM images.

The crystalline structure of $\mathrm{Cu}$-tpa MOF and $\mathrm{CuPt} / \mathrm{NC}$ (pyrolyzed) was determined with powder XRD as shown in (Figure 5). XRD pattern of Cu-tpa MOF has been transformed after pyrolysis because of the removal of unstable organic linker groups and the formation of nano-porous carbon. $\mathrm{Cu}$ and $\mathrm{Pt}$ 
peaks are dominant peaks in the $\mathrm{CuPt} / \mathrm{NC}$. XRD graph of $\mathrm{CuPt} / \mathrm{NC}$ shows sharp peak of $\mathrm{Cu}(111)$ at $42.7^{\circ}, \mathrm{Cu}(200)$ at $50.7^{\circ}, \mathrm{CuO}(-202)$ at $49.5^{\circ}, \mathrm{CuO}(202)$ at 59.2 [30], and XRD peak of Pt at (111) and (200) was observed at $2 \theta$ of $41.2^{\circ}$ and $45.2^{\circ}$ [31]. The positive shift of the diffraction peaks of CuPt/NC is due to incorporation of $\mathrm{Cu}$ atom into Pt structure. Moreover, a slight hump between 25 and $30^{\circ}$ indicates the presence of nano-porous carbon. (Figure 5) [4]. A little hump between 25-30 indicates the presence of nano porous carbon (Figure 5).
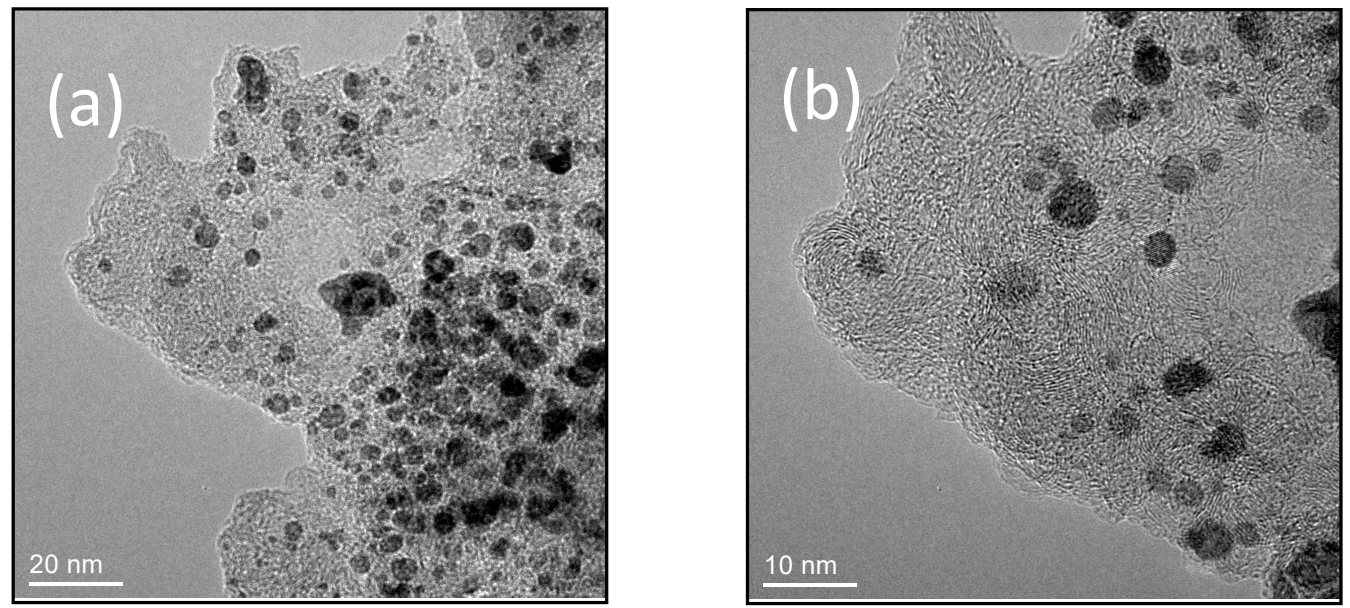

Figure 4. Transmission electron micrographs for CuPt/NC (a) $20 \mathrm{~nm}$ and (b) $10 \mathrm{~nm}$.
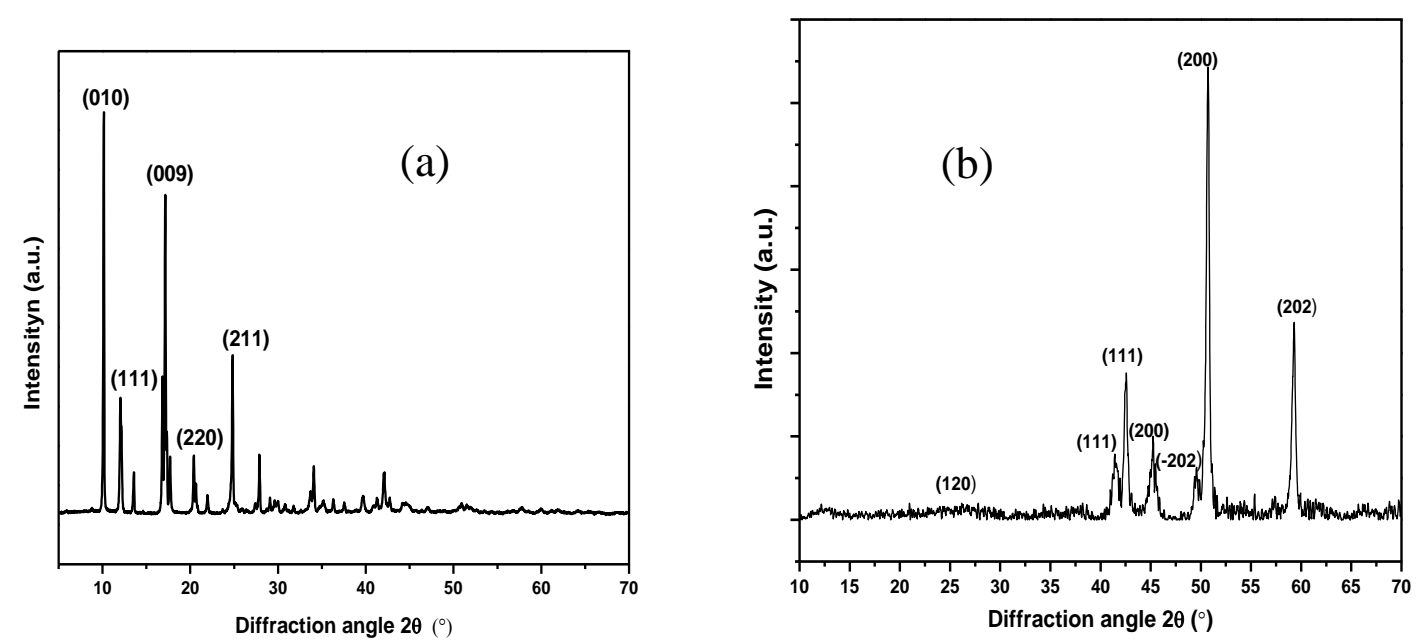

Figure 5. XRD patterns of (a) Cu-tpa MOF, (b) CuPt/NC with (hkl) values.

Figure 6 displays the XPS spectra of $\mathrm{CuPt} / \mathrm{NC}$ which confirms the same surface composition as that of the bulk. XPS further confirms the presence of $\mathrm{Pt}$. $\mathrm{Pt}(4 \mathrm{f})$ and $\mathrm{Cu}(2 \mathrm{p})$ peaks were observed at $71.5 \mathrm{eV}$ and $932.9 \mathrm{eV}$, both the peaks shifted toward higher binding energies as compared to pure $\mathrm{Pt}$ $(71.2 \mathrm{eV})$ and pure $\mathrm{Cu}(932.7 \mathrm{eV})$. The shift in peaks along with the $\mathrm{Pt}(4 \mathrm{f})$ peak broadening is attributed to $\mathrm{Cu}-\mathrm{Pt}$ metal interaction and the formation of $\mathrm{CuPt}$ nanoparticles on carbon framework [32,33]. The $\mathrm{C} 1 \mathrm{~s}$ is aligned at $284.42 \mathrm{eV}$ to compensate for the sample surface charging. Similarly oxygen spectrum deconvoluted into three peaks positioned at 530.15, 531.81, and $532.41 \mathrm{eV}$ represents $\mathrm{M}-\mathrm{O}$, $\mathrm{C}=\mathrm{O}$, and C-O respectively [34].

\section{Electrode Preparation and Electrochemical Evaluation}

For evaluation of electrochemical performance, catalyst ink was prepared by dissolving $2 \mathrm{mg}$ of catalyst $(\mathrm{Cu} / \mathrm{NC}, \mathrm{CuPt} / \mathrm{NC}$, and commercial Pt/C catalyst $46.1 \mathrm{wt} \%$ Tanaka Kikinzoku Kogyo, TEC10E50E) in $1 \mathrm{~mL}$ of stock solution. The suspension was sonicated in ultrasonic bath for $30 \mathrm{~min}$. 
Stock solution was prepared by mixing together $7.6 \mathrm{~mL}$ of DI water, $2.4 \mathrm{~mL}$ of iso-propyl alcohol, and $0.1 \mathrm{~mL}$ of $5 \mathrm{wt} \%$ NAFION $^{\mathrm{TM}}$ dispersion (Ion power LQ-1105-1100 EW) [25]. The catalyst electrode film was prepared on glassy carbon electrode (with diameter of $5 \mathrm{~mm}$ from Pine Research AFE5T050GC) by dropping $10 \mu \mathrm{m}$ of ink on it and dried for $20 \mathrm{~min}$ at $700 \mathrm{rpm}$. The thin films of commercial $\mathrm{Pt} / \mathrm{C}$ and $\mathrm{Cu} / \mathrm{NC}$ were also deposited for comparison. The three electrode assembly system was used for electrochemical measurements. Pt wire was used as counter electrode and saturated calomel electrode (SCE) as reference electrode. To test the ORR activity, cyclic voltammetry (CV) and linear sweep voltammetry (LSV) measurements for $\mathrm{CuPt} / \mathrm{NC}$ and $\mathrm{Pt} / \mathrm{C}$ catalysts were taken on rotating disk electrode in $0.1 \mathrm{M} \mathrm{HClO}_{4}$ solution. The solution was purged with $\mathrm{N}_{2}$ and $\mathrm{O}_{2}$ gases for 20-30 min before the electrochemical tests [35]. LSV tests were performed at 400, 800, 1200, and $1600 \mathrm{rpm}$. All the electrochemical tests were conducted at voltage scan rate of $30 \mathrm{mV} \mathrm{s}^{-1}$.
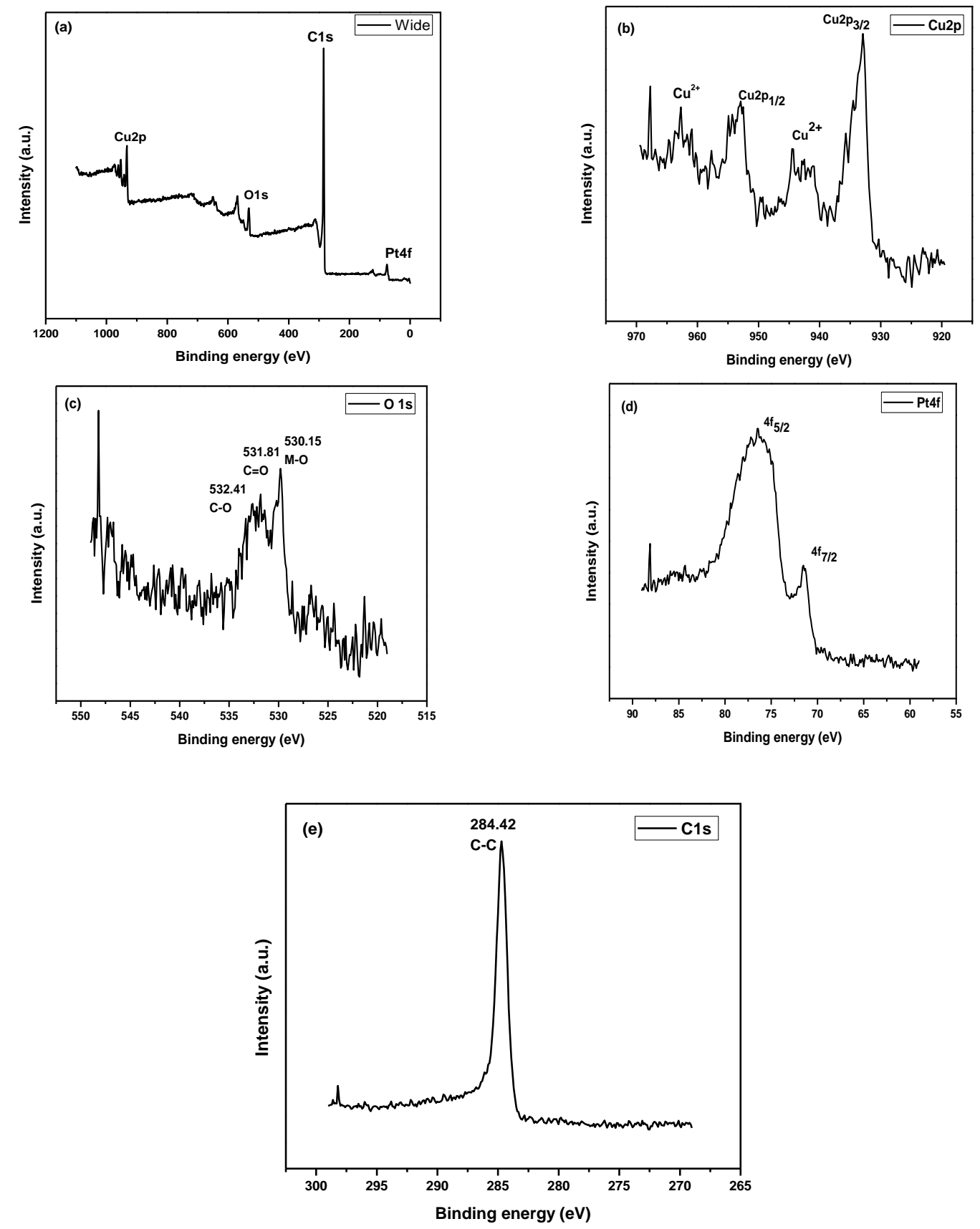

Figure 6. (a) XPS wide spectrum of $\mathrm{CuPt} / \mathrm{NC}$ and individual XPS scans of (b) Cu2p, (c) O1s, (d) Pt4f, (e) C1s. 
For the electrochemical testing of CuPt/NC, first cyclic voltammetry $(\mathrm{CV})$ was performed in $0.1 \mathrm{M}$ $\mathrm{HClO}_{4}$ with nitrogen saturation. No significant oxygen reduction peak was observed. With oxygen saturation, a distinct peak at a potential of $0.7 \mathrm{~V}$ is observed, which corresponds to oxygen reduction reaction (Figure 7a).
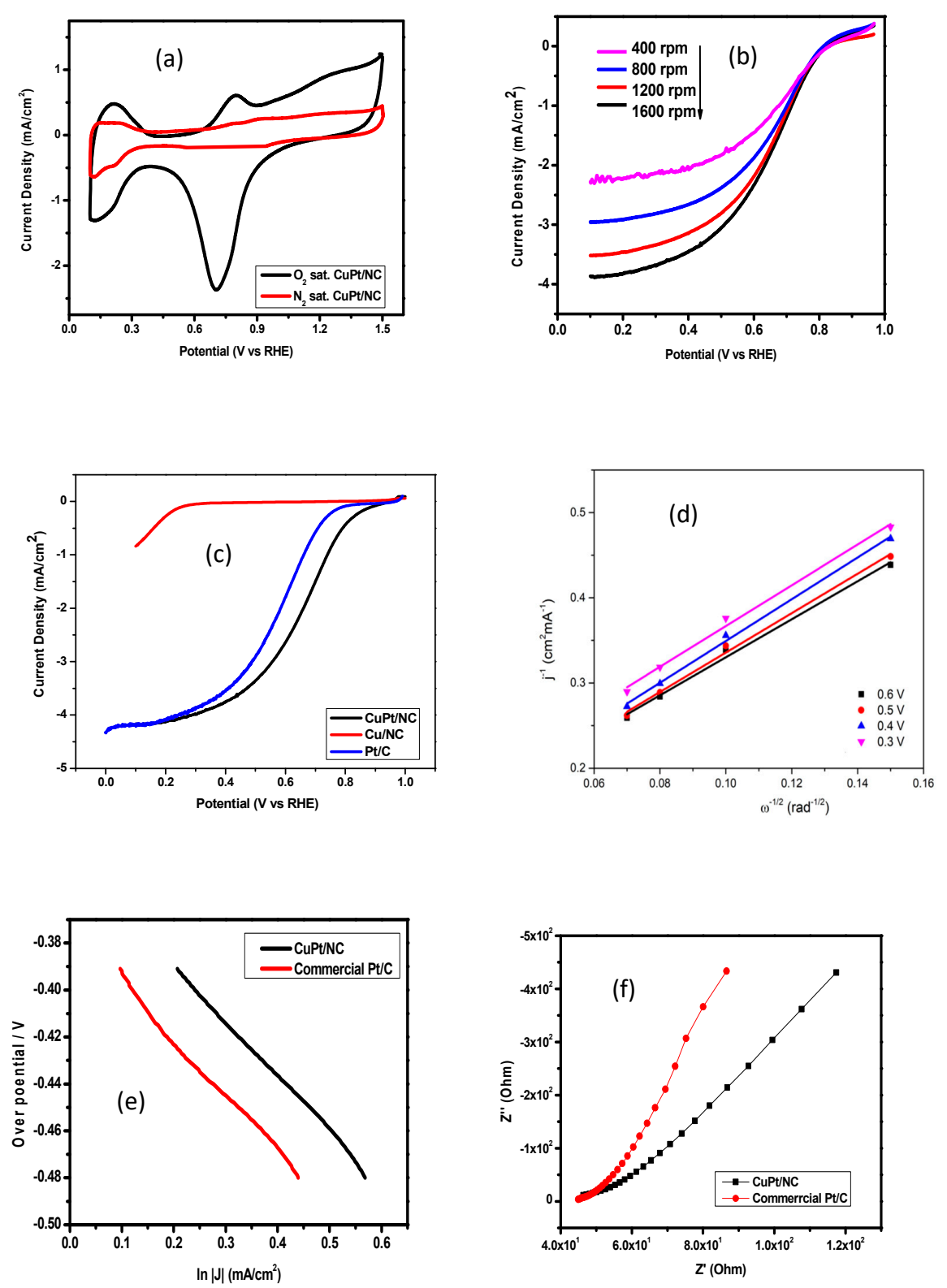

Figure 7. Evaluation of oxygen reduction reaction (ORR) activity for $\mathrm{CuPt} / \mathrm{NC}(\mathrm{a}) \mathrm{CV}$ plots (with nitrogen and oxygen saturation $0.1 \mathrm{M} \mathrm{HClO}_{4}$ solutions). (b) LSV plots at different rotation rates (rpm) for $\mathrm{CuPt} / \mathrm{NC}$. (c) Comparison of LSV curves of $\mathrm{Cu} / \mathrm{NC}, \mathrm{CuPt} / \mathrm{NC}$, and $\mathrm{Pt} / \mathrm{C}$ with $\mathrm{O}_{2}$ saturation in $0.1 \mathrm{M}$ $\mathrm{HClO}_{4}$ solution at $1600 \mathrm{rpm}$. (d) $\mathrm{K}-\mathrm{L}$ plots from $0.6 \mathrm{~V}$ to $0.3 \mathrm{~V}, \omega$ is the angular rotation speed. (e) Tafel slope comparison of $\mathrm{CuPt} / \mathrm{NC}$ and $\mathrm{Pt} / \mathrm{C}$ (f) Nyquist plots for $\mathrm{CuPt} / \mathrm{NC}$ and commercial Pt/C.

Further ORR activity of $\mathrm{CuPt} / \mathrm{NC}$ is evaluated by linear sweep voltammetry (LSV) measurements at different rotations with $\mathrm{RDE}$, which gives limiting current of $4 \mathrm{~mA} \mathrm{~cm}^{-2}$ at $1600 \mathrm{rpm}$ for CuPt/NC (Figure $7 \mathrm{~b}$ ). ORR activity of $\mathrm{CuPt} / \mathrm{NC}$ was compared with commercial $\mathrm{Pt} / \mathrm{C}$. CuPt/NC has the highest onset potential of $0.9 \mathrm{~V}$ while the value is $0.85 \mathrm{~V}$ for the commercial $\mathrm{Pt} / \mathrm{C}$ catalyst. $\mathrm{The} \mathrm{Cu} / \mathrm{NC}$ has a very low onset potential of $0.26 \mathrm{~V}$. So CuPt/NC showed $50 \mathrm{mV}$ more positive onset potential than the commercial Pt/C catalyst (Figure 7c). 
The mechanism of the ORR has been confirmed through the Koutecky-Levich (K-L) analysis (Figure 7d). The K-L plots show good linearity, which is assigned to the first order kinetics of ORR, and both catalysts are found to follow similar mechanistic pathways. The number of electrons (n) transferred during the reaction has been calculated from the slope of the K-L plot by following equation:

$$
\mathrm{B}=0.2 \mathrm{nF}\left(\mathrm{Do}_{2}\right)^{2 / 3} \mathrm{~V}^{-1 / 6} \mathrm{Co}_{2}
$$

In Equation (2), $\mathrm{F}$ is Faraday constant $(\mathrm{F}=96,500)$, $\mathrm{n}$ shows number of electrons transferred per $\mathrm{O}_{2}$ molecules, $\mathrm{Do}_{2}$ is the diffusion coefficient of oxygen molecule in electrolyte, $\mathrm{V}$ is kinetic viscosity, and $\mathrm{Co}_{2}$ shows bulk quantity/concentration of oxygen and when rotation speed is expressed in rpm then constant 0.2 is adopted [11], transferred number of electrons lies between 3.93 and 3.97 for the voltage range of $0.3-0.6 \mathrm{~V}$ [35]. Charge transfer number for commercial $\mathrm{Pt} / \mathrm{C}$ is 4.00 , as it follows 4 e pathway for $\mathrm{ORR}$ and the $\mathrm{n}$ calculated for $\mathrm{CuPt} / \mathrm{NC}$ is close to 4.00 therefore it also follows $4 \mathrm{e}$ pathway $[14,36,37]$.

The mechanism of ORR and quality of the electrocatalyst can be obtained from Tafel analysis. Tafel slope provides an indication of the actual mechanism taking place on the electrode surface and is related to the state of the adsorbed oxygen species and its coverage variation with respect to the potential. The over potential is calculated by the formula $\left(E-E_{0}\right)$ [22]. Furthermore, to identify the kinetic resistance of the reaction, charge transfer coefficients $(\alpha)$ were calculated for the catalysts by following Equation (3):

$$
\frac{\mathrm{d} \eta}{\mathrm{d} \ln |\mathrm{j}|}=-\frac{1.857 R T}{\alpha n F}
$$

The Tafel slopes of Pt/C and CuPt/NC are found to be $190 \mathrm{mV} \mathrm{dec}^{-1}$ and $213 \mathrm{mV} \mathrm{dec}^{-1}$ (Figure 7e). Tafel slopes $>118 \mathrm{mV} / \mathrm{dec}$ attributed to either (i) a preceding chemical dissociation or (ii) a consequent chemical combination as well as (iii) an electrode transfer through an oxide layer. In order to avoid misperception, the values chosen up from the Tafel slopes will be cited as "cathodic quantities" in the subsequent sections, as these will directly be used for the investigation of the ORR mechanisms [38]. The results are in accordance with literature, as the low potential region describes first $\mathrm{C}-\mathrm{H}$ bond breaking in oxygen reduction reaction and it is the rate-determining step because of first electron transfer. Though, at high potential region, the slope values increase because of less exposure of poisonous intermediate species [14,39,40].

Electrochemical impedance spectroscopy (EIS) is also used to determine the electrochemical activity of modified electrode. Charge transfer resistance is measured from Nyquist plots, the lower slope of the plot represents the lower charge transfer resistance. Figure $7 \mathrm{f}$ shows that the Nyquist plots of $\mathrm{CuPt} / \mathrm{NC}$ exhibit lower slope than $\mathrm{Pt} / \mathrm{C}$ which interprets that the charge transfer resistance for the $\mathrm{CuPt} / \mathrm{NC}$ is less than that of the commercial $\mathrm{Pt} / \mathrm{C}[41,42]$. The overall ORR performance comparison of $\mathrm{CuPt} / \mathrm{NC}$ and commercial $\mathrm{Pt} / \mathrm{C}$ along with kinetics parameters is shown in Table 2.

Table 2. Comparison of ORR performance for $\mathrm{CuPt} / \mathrm{NC}$ and commercial Pt/C.

\begin{tabular}{ccc}
\hline Electrochemical Properties & CuPt/NC & Pt/C \\
\hline Onset potential & $0.9 \mathrm{~V} \mathrm{(vs.} \mathrm{RHE)}$ & $0.85 \mathrm{~V} \mathrm{(vs.} \mathrm{RHE)}$ \\
Peak current density & $4.2 \mathrm{~mA} \mathrm{~cm}^{-2}$ & $4.32 \mathrm{~mA} \mathrm{~cm}^{-2}$ \\
Tafel slope & $213 \mathrm{mV} \mathrm{dec}^{-1}$ & $190 \mathrm{mV} \mathrm{dec}^{-1}$ \\
Electron transfer number & $\sim 4$ & 4 \\
Charge transfer coefficient & 0.035 & 0.027 \\
\hline
\end{tabular}

Figure 8 shows the proposed mechanism of oxygen reduction reaction in acidic solution i.e., $\left(\mathrm{HClO}_{4}\right)$. Molecular oxygen $\left(\mathrm{O}_{2}\right)$ in solution phase adsorbs first on the surface of electrode. Electrochemical reduction starts from the adsorbed state with $\mathrm{K}_{1}$ constant either directly to $\mathrm{H}_{2} \mathrm{O}$ or to adsorbed $\mathrm{H}_{2} \mathrm{O}_{2}$ as an intermediate that could additionally be reduced to water, by the constant $\mathrm{k}_{3}$, where reduction still continues via direct 4e pathway, or desorption of peroxide as the reaction final 
product, disband into the solution ensuing 2e pathway. In addition, it includes chemical decomposition of two molecules of hydrogen peroxide to water and oxygen.

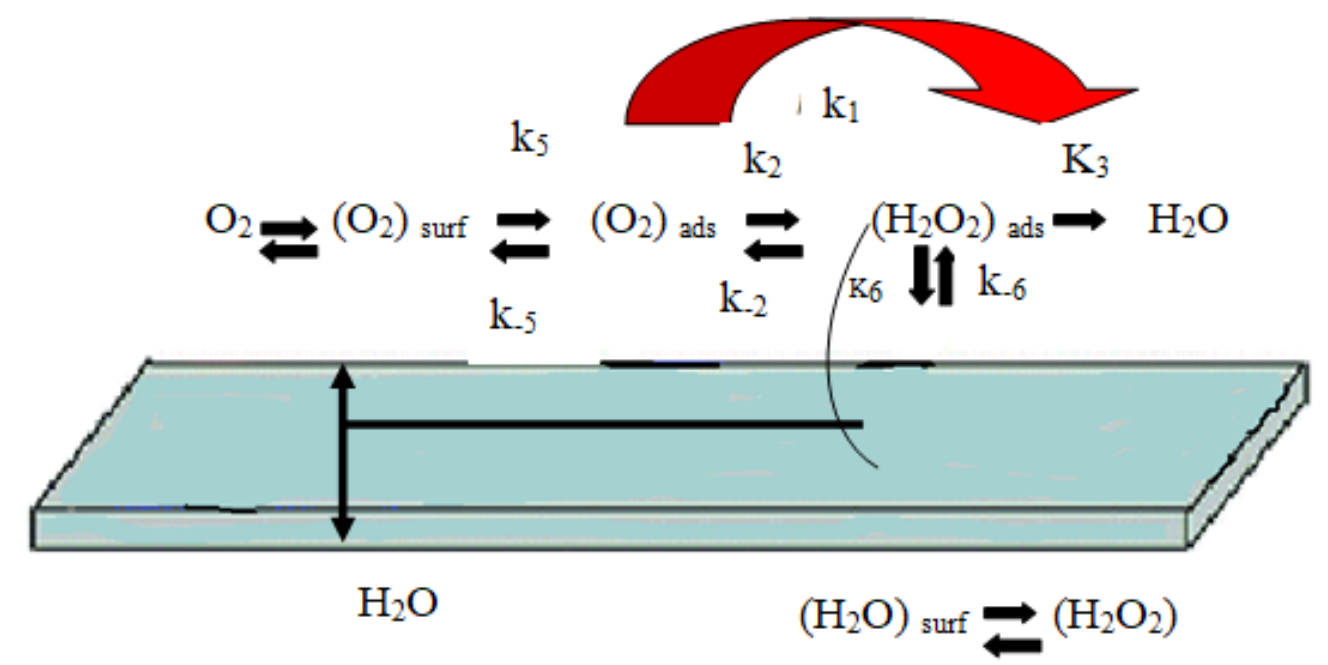

Figure 8. Mechanism of oxygen reduction reaction on the surface of electrode.

\section{Experimental}

\subsection{Materials}

All chemicals and reagents were purchased from Sigma-Aldrich without any additional purification. Chemicals used were copper nitrate trihydrate salt $\left(\mathrm{CuNO}_{3} \cdot 3 \mathrm{H}_{2} \mathrm{O}\right)$, terephthalic acid $\left(\mathrm{C}_{8} \mathrm{H}_{6} \mathrm{O}_{4}\right)$, commercial grade chloroplatinic acid $\left(\mathrm{H}_{2} \mathrm{PtCl}_{6}\right), \mathrm{N}, \mathrm{N}$-dimethylformamide (DMF), ethanol $\left(\mathrm{C}_{2} \mathrm{H}_{5} \mathrm{OH}\right)$, perchloric acid $\left(\mathrm{HCLO}_{4}\right)$, and $5 \mathrm{wt} \%$ Nafion were purchased from Sigma-Aldrich. For preparing aqueous solutions deionized (DI) water was used and distilled water was utilized for washing purpose during catalyst synthesis.

\subsection{Catalyst Characterization}

SEM images were taken on VEGA3 TESCON at $20 \mathrm{KV}$ at different magnifications. Elemental composition of prepared samples was determined by EDS. Siemens D5000 Powder X-ray diffractometer was used to identify the crystal structure. XRD data were collected between $2 \theta$ values of $10^{\circ}-70^{\circ}$ for $\mathrm{CuPt} / \mathrm{NC}$ and $\mathrm{Cu} \mathrm{K} \alpha$ was used as an X-ray source. The FTIR spectrum was acquired by using Agilent Cary 630 spectrophotometer. Transmission electron microscopy (TEM) was performed on CM200-FEG (Philips) at $200 \mathrm{keV}$. The XPS was performed on VG 220i-XL.

\subsection{Synthesis of $\mathrm{Cu}$-tpa $\mathrm{MOF}$}

In a typical synthesis, $5 \mathrm{~g}$ of $\mathrm{CuNO}_{3} \cdot 3 \mathrm{H}_{2} \mathrm{O}$ was dissolved in $40 \mathrm{~mL}$ of deionized (DI) water. Total of $2 \mathrm{~g}$ of terephthalic acid was dissolved in a mixture of $40 \mathrm{~mL} \mathrm{~N}, \mathrm{~N}$-dimethyl formamide (DMF) and 40 $\mathrm{mL}$ of ethanol. Both solutions were mixed by stirring at $80^{\circ} \mathrm{C}$ for $24 \mathrm{~h}$ on a hot plate. The blue powder obtained was centrifuged and subsequently washed with DMF and DI water. The collected powder was dried at $80^{\circ} \mathrm{C}$ in a vacuum oven.

\subsection{Synthesis of $\mathrm{CuPt} / \mathrm{NC}$}

For the synthesis of $\mathrm{CuPt} / \mathrm{NC} 100 \mathrm{mg}$ of $\mathrm{Cu}$-tpa, MOF was mixed with $0.1 \mathrm{~mL}$ of $(96.5 \mathrm{mM})$ $\mathrm{H}_{2} \mathrm{PtCl}_{6} \cdot \mathrm{H}_{2} \mathrm{O}\left(5 \mathrm{wt} \%\right.$ solution) and the mixture was dried at $80^{\circ} \mathrm{C}$ for $2 \mathrm{~h}$ (Figure 9 ). The dried powder was heated to $350{ }^{\circ} \mathrm{C}$ for $1.5 \mathrm{~h}$ by placing in ceramic boat in a tube furnace and then heated to $700{ }^{\circ} \mathrm{C}$ with a temperature ramp of $2{ }^{\circ} \mathrm{C} \mathrm{min}-1$. It was then kept at $700{ }^{\circ} \mathrm{C}$ for $3.5 \mathrm{~h}$ under the constant flow of $\mathrm{Ar}-\mathrm{H}_{2}(90 \%$ Ar) mixture in the tube furnace. After cooling down, the black pyrolyzed powder was acid 
washed with $0.5 \mathrm{M} \mathrm{H}_{2} \mathrm{SO}_{4}$ and centrifuged. It was then subjected to multiple washings with DI water and subsequently dried at $80^{\circ} \mathrm{C}$ in vacuum oven. Pt loading was calculated on the basis of pyrolyzed sample weight and $\mathrm{H}_{2} \mathrm{PtCl}_{6}$ loading. $\mathrm{Cu} / \mathrm{NC}$ was synthesized by the same method without $\mathrm{Pt}$ loading.

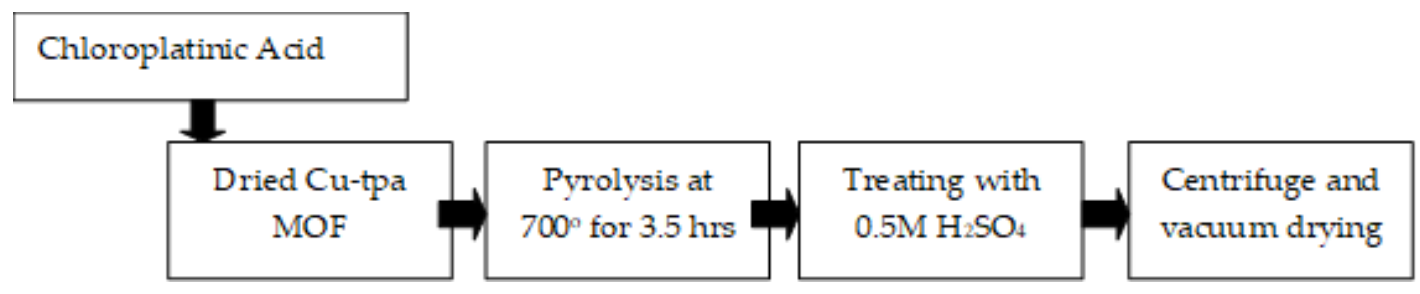

Figure 9. Systematic procedure for the synthesis of $\mathrm{CuPt} / \mathrm{NC}$ catalyst.

\section{Conclusions}

This work demonstrated a highly active and efficient CuPt/NC ORR catalyst derived from Cu-tpa MOF. Characterization through SEM indicates the Pt loading on nanoporous carbon. TEM images display uniformity of CuPt nanoparticles. Shift in binding energy of Cu2p and Pt4f in XPS is interpreted as $\mathrm{Cu}$-Pt interaction. The onset potential of $\mathrm{CuPt} / \mathrm{NC}$ is $0.9 \mathrm{~V}$ (vs. RHE) and the value of limiting current density is $4 \mathrm{~mA} / \mathrm{cm}^{2}$. Furthermore, the linearity of K-L plots and the charge transfer number value of 3.93-3.97 indicated single step kinetics. Tafel slope also shows that $\mathrm{CuPt} / \mathrm{NC}$ and commercial $\mathrm{Pt} / \mathrm{C}$ follows the same reaction kinetics. From EIS studies it was concluded that $\mathrm{CuPt} / \mathrm{NC}$ has lower charge transfer resistance than $\mathrm{Pt} / \mathrm{C}$. Hence the results emphasize the excellent activity of $\mathrm{CuPt} / \mathrm{NC}$ as a potential ORR catalyst.

Author Contributions: Conceptualization, N.I. and R.A.; methodology, R.A.; formal analysis, R.A., X.S. and S.H.; investigation, R.A.; data curation, R.A., D.H., S.A.M.R. and X.S.; writing-original draft preparation, R.A. and N.Z.; writing-review and editing, N.I., T.N. and, A.M.K.; supervision, N.I. and A.M.K. All authors have read and agreed to the published version of the manuscript.

Funding: This research was funded by PSF under Project No. PSF-NSF/Eng/C-NUST (04).

Acknowledgments: The authors would like to thank USAID and U.S.-Pakistan Centers for Advanced Studies in Energy for the financial support. We acknowledge the use of facilities within the Eyring Materials Center and School of Earth and Space Exploration at Arizona State University.

Conflicts of Interest: The authors declare that they have no known competing financial interests or personal relationships that could have appeared to influence the work reported in this paper.

\section{References}

1. Wang, Y.; Chen, K.S.; Mishler, J.; Cho, S.C.; Adroher, X.C. A review of polymer electrolyte membrane fuel cells: Technology, applications, and needs on fundamental research. Appl. Energy 2011, 88, 981-1007. [CrossRef]

2. Winter, M.; Brodd, R.J. What Are Batteries, Fuel Cells, and Supercapacitors? ACS Publications: Washington, DC, USA, 2004.

3. Savinell, R.F.; Ota, K.-I.; Kreysa, G. Encyclopedia of Applied Electrochemistry; Springer: Berlin, Germany, 2014.

4. Rizvi, S.A.M.; Iqbal, N.; Haider, M.D.; Noor, T.; Anwar, R.; Hanif, S. Synthesis and Characterization of Cu-MOF Derived Cu@ AC Electrocatalyst for Oxygen Reduction Reaction in PEMFC. Catal. Lett. 2019, 20, 1-11. [CrossRef]

5. Ge, X.; Sumboja, A.; Wuu, D.; An, T.; Li, B.; Goh, F.T.; Hor, T.A.; Zong, Y.; Liu, Z. Oxygen reduction in alkaline media: From mechanisms to recent advances of catalysts. ACS Catal. 2015, 5, 4643-4667. [CrossRef]

6. Khotseng, L. Oxygen Reduction Reaction. In Electrocatalysts for Fuel Cells and Hydrogen Evolution-Theory to Design; IntechOpen: London, UK, 2018.

7. Xia, B.Y.; Yan, Y.; Li, N.; Wu, H.B.; Lou, X.W.D.; Wang, X. A metal-organic framework-derived bifunctional oxygen electrocatalyst. Nat. Energy 2016, 1, 1-8. [CrossRef]

8. Suntivich, J.; Gasteiger, H.A.; Yabuuchi, N.; Nakanishi, H.; Goodenough, J.B.; Shao-Horn, Y. Design principles for oxygen-reduction activity on perovskite oxide catalysts for fuel cells and metal-air batteries. Nat. Chem. 2011, 3, 546-550. [CrossRef] [PubMed] 
9. Daud, W.R.W.; Rosli, R.; Majlan, E.; Hamid, S.; Mohamed, R.; Husaini, T. PEM fuel cell system control: A review. Renew. Energy 2017, 113, 620-638. [CrossRef]

10. Tian, J.; Wu, W.; Tang, Z.; Wu, Y.; Burns, R.; Tichnell, B.; Liu, Z.; Chen, S. Oxygen reduction reaction and hydrogen evolution reaction catalyzed by $\mathrm{Pd}-\mathrm{Ru}$ nanoparticles encapsulated in porous carbon nanosheets. Catalysts 2018, 8, 329. [CrossRef]

11. Zhang, J.; Xia, Z.; Dai, L. Carbon-based electrocatalysts for advanced energy conversion and storage. Sci. Adv. 2015, 1, e1500564. [CrossRef]

12. Kiani, M.; Zhang, J.; Luo, Y.; Jiang, C.; Fan, J.; Wang, G.; Chen, J.; Wang, R. Recent developments in electrocatalysts and future prospects for oxygen reduction reaction in polymer electrolyte membrane fuel cells. J. Energy Chem. 2018, 27, 1124-1139. [CrossRef]

13. Hernández-Ramírez, A.; Sánchez-Castro, M.; Alonso-Lemus, I.; Aruna, K.K.; Karthikeyan, P.; Manoharan, R.; Rodríguez-Varela, F. Evaluation of the nickel titanate-modified Pt nanostructured catalyst for the ORR in alkaline media. J. Electrochem. Soc. 2016, 163, F16-F24. [CrossRef]

14. Dhavale, V.M.; Kurungot, S. Cu-Pt nanocage with 3-D electrocatalytic surface as an efficient oxygen reduction electrocatalyst for a primary Zn-Air battery. ACS Catal. 2015, 5, 1445-1452. [CrossRef]

15. Bruce, P.G.; Freunberger, S.A.; Hardwick, L.J.; Tarascon, J.-M. Li-O 2 and Li-S batteries with high energy storage. Nat. Mater. 2012, 11, 19. [CrossRef] [PubMed]

16. Shi, X.; Pérez-Salcedo, K.; Hanif, S.; Anwar, R.; Cindrella, L.; Iqbal, N.; Jose, S.; Kannan, A. Progress on the Functionalization of Carbon Nanostructures for Fuel Cell Electrocatalysts. In Advanced Electrocatalysts for Low-Temperature Fuel Cells; Springer: Berlin, Germany, 2018; pp. 215-234.

17. Wang, M. Novel Nanostructured Electrocatalysts for Fuel Cells. Ph.D. Thesis, University of Wollongong, Wollongong, Australia, 2015.

18. Mamtani, K.; Bruening, C.; Co, A. A Comparison of Oxygen Reduction Reaction (ORR) Performance for Iron-Nitrogen-Carbon (FeNC) Catalysts in Acidic and Alkaline Media. Res. Rev. Electrochem. 2017, 8, 1-9.

19. Yaqoob, L.; Noor, T.; Iqbal, N.; Nasir, H.; Zaman, N. Development of Nickel-BTC-MOF-Derived Nanocomposites with rGO Towards Electrocatalytic Oxidation of Methanol and Its Product Analysis. Catalysts 2019, 9, 856. [CrossRef]

20. Khan, J.; Iqbal, N.; Asghar, A.; Noor, T. Novel amine functionalized metal organic framework synthesis for enhanced carbon dioxide capture. Mater. Res. Express 2019, 6, 105539. [CrossRef]

21. Noor, T.; Ammad, M.; Zaman, N.; Iqbal, N.; Yaqoob, L.; Nasir, H. A Highly Efficient and Stable Copper BTC Metal Organic Framework Derived Electrocatalyst for Oxidation of Methanol in DMFC Application. Catal. Lett. 2019, 149, 1-16. [CrossRef]

22. Noor, T.; Zaman, N.; Nasir, H.; Iqbal, N.; Hussain, Z. Electro catalytic study of NiO-MOF/rGO composites for methanol oxidation reaction. Electrochim. Acta 2019, 307, 1-12. [CrossRef]

23. Wang, H.-F.; Chen, L.; Pang, H.; Kaskel, S.; Xu, Q. MOF-derived electrocatalysts for oxygen reduction, oxygen evolution and hydrogen evolution reactions. Chem. Soc. Rev. 2020, 49, 1414-1448. [CrossRef]

24. Wang, R.; Dong, X.Y.; Du, J.; Zhao, J.Y.; Zang, S.Q. MOF-Derived bifunctional Cu3P nanoparticles coated by a N, P-codoped carbon shell for hydrogen evolution and oxygen reduction. Adv. Mater. 2018, 30, 1703711. [CrossRef]

25. Shinozaki, K.; Zack, J.W.; Richards, R.M.; Pivovar, B.S.; Kocha, S.S. Oxygen reduction reaction measurements on platinum electrocatalysts utilizing rotating disk electrode technique I. Impact of impurities, measurement protocols and applied corrections. J. Electrochem. Soc. 2015, 162, F1144-F1158. [CrossRef]

26. Butler, I.B.; Schoonen, M.A.; Rickard, D.T. Removal of dissolved oxygen from water: A comparison of four common techniques. Talanta 1994, 41, 211-215. [CrossRef]

27. Wang, W.; Wang, Q.; Wang, Q.; Gao, F.; Gao, F.; Yang, Y.; Guo, H. Highly dispersible and stable copper terephthalate metal-organic framework-graphene oxide nanocomposite for an electrochemical sensing application. ACS Appl. Mater. Interfaces 2014, 6, 11573-11580. [CrossRef]

28. Kruk, M.; Jaroniec, M. Gas adsorption characterization of ordered organic-inorganic nanocomposite materials. Chem. Mater. 2001, 13, 3169-3183. [CrossRef]

29. Zhang, W.; Meng, S.; Wang, H.; He, Y. Metal organic frameworks enhanced graphene oxide electrode for humidity sensor. J. Phys. Conf. Ser. 2018, 986, 012013. [CrossRef]

30. Ashok, C.; Rao, K.V.; Chakra, C.S. Structural analysis of $\mathrm{CuO}$ nanomaterials prepared by novel microwave assisted method. J. Atoms Mol. 2014, 4, 803-806. 
31. Su, L.; Shrestha, S.; Zhang, Z.; Mustain, W.; Lei, Y. Platinum-copper nanotube electrocatalyst with enhanced activity and durability for oxygen reduction reactions. J. Mater. Chem. A 2013, 1, 12293-12301. [CrossRef]

32. Peng, H.; Qi, W.; Wu, H.; He, J.; Li, Y.; Xie, H. One-pot synthesis of CuPt nanodendrites with enhanced activity towards methanol oxidation reaction. RSC Adv. 2018, 8, 9293-9298. [CrossRef]

33. Wakisaka, M.; Mitsui, S.; Hirose, Y.; Kawashima, K.; Uchida, H.; Watanabe, M. Electronic structures of Pt-Co and Pt-Ru alloys for CO-tolerant anode catalysts in polymer electrolyte fuel cells studied by EC-XPS. J. Phys. Chem. B 2006, 110, 23489-23496. [CrossRef] [PubMed]

34. Ganguly, A.; Sharma, S.; Papakonstantinou, P.; Hamilton, J. Probing the thermal deoxygenation of graphene oxide using high-resolution in situ X-ray-based spectroscopies. J. Phy. Chem. C 2011, 115, 17009-17019. [CrossRef]

35. Zhou, R.; Zheng, Y.; Jaroniec, M.; Qiao, S.-Z. Determination of the electron transfer number for the oxygen reduction reaction: From theory to experiment. ACS Catal. 2016, 6, 4720-4728. [CrossRef]

36. Shi, R.; Zhao, J.; Liu, S.; Sun, W.; Li, H.; Hao, P.; Li, Z.; Ren, J. Nitrogen-doped graphene supported copper catalysts for methanol oxidative carbonylation: Enhancement of catalytic activity and stability by nitrogen species. Carbon 2018, 130, 185-195. [CrossRef]

37. Sa, Y.J.; Seo, D.-J.; Woo, J.; Lim, J.T.; Cheon, J.Y.; Yang, S.Y.; Lee, J.M.; Kang, D.; Shin, T.J.; Shin, H.S. A general approach to preferential formation of active Fe-N x sites in Fe-N/C electrocatalysts for efficient oxygen reduction reaction. J. Am. Chem. Soc. 2016, 138, 15046-15056. [CrossRef]

38. Nunes, M.; Rocha, I.M.; Fernandes, D.M.; Mestre, A.S.; Moura, C.N.; Carvalho, A.P.; Pereira, M.F.; Freire, C. Sucrose-derived activated carbons: Electron transfer properties and application as oxygen reduction electrocatalysts. RSC Adv. 2015, 5, 102919-102931. [CrossRef]

39. Chiwata, M.; Kakinuma, K.; Wakisaka, M.; Uchida, M.; Deki, S.; Watanabe, M.; Uchida, H. Oxygen reduction reaction activity and durability of Pt catalysts supported on titanium carbide. Catalysts 2015, 5, 966-980. [CrossRef]

40. Shinagawa, T.; Garcia-Esparza, A.T.; Takanabe, K. Insight on Tafel slopes from a microkinetic analysis of aqueous electrocatalysis for energy conversion. Sci. Rep. 2015, 5, 13801. [CrossRef]

41. Mehek, R.; Iqbal, N.; Noor, T.; Nasir, H.; Mehmood, Y.; Ahmed, S. Novel Co-MOF/graphene oxide electrocatalyst for methanol oxidation. Electrochim. Acta 2017, 255, 195-204. [CrossRef]

42. Hanif, S.; Shi, X.; Iqbal, N.; Noor, T.; Anwar, R.; Kannan, A. ZIF derived PtNiCo/NC cathode catalyst for proton exchange membrane fuel cell. Appl. Catal. B Environ. 2019, 258, 117947. [CrossRef] 